\title{
Percepcja i postrzeganie formy jako wytyczne dla kształtowania panoramy miasta
}

\author{
Karolina Sobczyńska \\ https://orcid.org/0000-0002-3105-7195 \\ karolina.sobczynska@put.poznan.pl \\ Instytut Architektury, Urbanistyki i Ochrony Dziedzictwa, \\ Wydziat Architektury, Politechnika Poznańska
}

\begin{abstract}
Streszczenie: Panorama miasta, podobnie jak każda przestrzeń, stanowi kompozycję, która jest złożona z wielu form. Percepcja panoramy miasta będzie więc postrzeganiem formy, kształtów, rytmów poszczególnych elementów i ich hierarchii. Przestrzeń architektoniczna wywołuje w obserwatorze wiele doznań. Jest ona dla człowieka zrozumiała i postrzegana jako czytelna, jeśli jest uformowana dobitnie i jednoznacznie. Dlatego zasady percepcji i postrzegania formy powinny być jedną z wytycznych kształtowania przestrzeni urbanistycznej miasta, a także jego widoków panoramicznych. Kształt sylwety miasta w widokach panoramicznych jest często elementem jego indywidualności stąd istotna jest dbałość o zachowanie zasad istniejącej kompozycji i hierarchii.
\end{abstract}

Słowa kluczowe: panorama, percepcja, forma, kompozycja, hierarchia

\section{Percepcja miasta}

\section{Proces percepcji jako zagadnienie}

Procesem percepcji zajmowało się wielu badaczy. Na przykład Ittelson (1973) uważa, że proces percepcji związany jest z postrzeganiem i poznawaniem środowiska przy pomocy zmysłów. Człowiek identyfikuje przestrzeń za pomocą wszystkich zmysłów, z których najważniejszy jest wzrok, pozwalający widzieć, identyfikować kształty, obiekty i fragmenty przestrzeni, jak na przykład panoramy miejskie. Z kolei Gibson $(1979,1966)$ traktuje proces percepcyjny jako zjawisko holistyczne, w którym człowiek odbiera ze środowiska nie pojedyncze bodźce, lecz znaczenia całościowe [za: Bańka 2002: 57-61]. Bodźce płynące od przestrzeni miasta są bardzo złożone, ponieważ odbierane są wielozmysłowo i stąd wywołują złożone doznania. Natomiast widok panoramy miasta z daleka dostarcza człowiekowi mniej złożonych bodźców, głównie dlatego, że panorama miasta jest rejestrowana tylko przez zmysł wzroku obserwatora, a nie wszystkimi zmysłami, jak ma to miejsce podczas przebywania w mieście. Percepcja panoramy miasta będzie po prostu postrzeganiem formy, kształtu, rytmów elementów i ich hierarchii, a także barw obiektów.

\section{Psychosomatyczna budowa człowieka a postrzeganie form}

Juliusz Żórawski uważa, że "nie ma materii bez formy", to znaczy, że dla człowieka jego otoczenie, materia, zawsze posiada jakiś kształt, to znaczy jest jakąś formą. W swoim dziele "O budowie formy architektonicznej" analizuje formy i pokazuje, że materia może stanowić formę spoistą, swobodną, silną lub słabą, dobitną lub mniej dobitną i zależy to od sposobu uformowania, formy [Żórawski, 1973, s. 21]. Ponad to psychosomatyczna 
budowa człowieka wpływa na to, że w czasie obserwowania otoczenia, posiada on różne, głęboko zakorzenione tendencje, takie jak tendencja do geometryzacji, czy grupowania elementów, preferowanie form spoistych oraz kompozycji cięższych u dołu i smuklejszych u góry [Żórawski, 1973, s. 24]. Na przykład, gdy człowiek patrzy na panoramę miejską, to próbuje znaleźć w niej pewne geometryczne figury i łączące je zależności, próbuje grupować jej elementy w rytmy i grupy, poszukując znanych z wcześniejszych doświadczeń, zrozumiałych kształtów.

Kazimierz Wejchert [1984, s. 45] uważa, że w człowieku, obserwatorze przestrzeni miasta, powstają wrażenia ogólne pochodzące od całości obrazu, ale też następuje rejestracja cząstkowa niektórych elementów, po których przesuwa się jego wzrok. Dominujące doznanie powstaje w momencie, kiedy wzrok człowieka zatrzymuje się na formie architektonicznej, która w jakiś sposób wyróżnia się od pozostałych form lub formie, która stanowi główny punkt kompozycji przestrzennej. Wejchert zwraca uwagę na ważną rolę dominant w kompozycji miasta. Są one ważne dla obserwatora znajdującego się centrum miasta jak i człowieka obserwującego panoramę miasta, jego sylwetę z oddali. Obiekty, które wyróżniają się na tle innych i przyciągają swoim ukształtowaniem bądź wielkością uwagę obserwatora są zwykle dominantami kompozycji panoramy. Dominanty są dla miast charakterystycznymi i orientacyjnymi elementami, które często wpływają na ich indywidualność i niepowtarzalność.

Przestrzeń architektoniczna wywołuje w obserwatorze wiele doznań. Jest ona dla człowieka zrozumiała i postrzegana jako czytelna, jeśli jest uformowana dobitnie i jednoznacznie. Dlatego projektowanie przestrzeni miasta powinno uwzględniać budowę psychosomatyczną człowieka i wynikające z niej preferencje, by doznania pochodzące od tej przestrzeni były pozytywne. Forma i przestrzeń miasta powinny stanowić uporządkowaną, czytelną kompozycję, by wywoływać poczucie bezpieczeństwa i odprężenia.

Wobec powyższego bardzo ważne jest, by projektanci przestrzeni miejskich, odpowiedzialnie podejmowali decyzje przestrzenne i przede wszystkim, świadomie stosowali różne elementy kompozycji, w zamierzony sposób, przewidując jednocześnie ich wpływ na doznania uczestników projektowanej przestrzeni [Sobczyńska, 2014].

\section{Panorama miasta jako kompozycja i forma - percepcja i postrzeganie}

\section{Kompozycje swobodne, spoiste a zależności pomiędzy elementami}

Każda przestrzeń, w tym również panorama miasta w widoku, składa się z wielu form. Jak zauważa Żórawski, jedne $z$ tych form są swobodne w kształcie lub rozmieszczeniu, a inne są spoiste, zwarte. Tym samym, niektóre z tych form są silne, a inne są słabsze, mniej dobitne w uformowaniu i mniej przyciągające uwagę. Według Żórawskiego człowiek najszybciej dostrzega formy silne i spoiste [1973, s. 28].

Formy silne zawsze wyróżniają się w jakiś sposób ze swojego otoczenia. Formy te odróżniają się od innych, znajdujących się w pobliżu i przyciągają uwagę obserwatora na przykład swoim kształtem, wielkością lub barwą. Na tle form swobodnych lub podobnych do siebie kształtem i rozmiarem, dominantą będzie forma spoista, która wyróżnia się spośród innych rozmiarem, kształtem, materiałem, itp. Przykład takiej dominanty, czyli formy spoistej na tle form swobodnych, można znaleźć w kompozycji średniowiecznych miast, gdzie wieża zamku, ratusza lub kościoła góruje nad pozostałymi budynkami. Na tle niskich budynków, wysoka wieża ratusza lub kościoła zawsze przyciągała uwagę i wzrok obserwatora.

Według Żórawskiego cechą formy spoistej jest to, że poszczególne jej części są ze sobą kompozycyjnie związane, a pomiędzy nimi występują różne wzajemne zależności. Odjęcie jakiejś części z kompozycji spoistej spowoduje wrażenie ubytku lub utrudni pojmowanie układu jako całości [Żórawski, 1973, s. 86]. Kiedy kompozycja spoista, zbudowana jest z form-części, to kompozycja ta, zależy od stosunków wielkości tych części względem całości. Panoramy miast można traktować jako formy (kompozycje) złożone z części. Należy zauważyć więc, że poszczególne części formy (kompozycji) panoramy miasta, podobnie jak wewnętrznej przestrzeni miasta, są we wzajemnych zależnościach względem siebie i względem formy (kompozycji) jako całości. Dlatego zmiana wielkości którejś z części kompozycji, spowoduje zmianę w całości lub nawet załamanie się równowagi stosunków i proporcji całości kompozycji. Jeżeli widziany układ urbanistyczny stanowi kompozycję silną i spoistą, to jej części są ze sobą ściśle związane. Na przykład zwarta, zabudowa średniowiecznego miasta w widoku panoramicznym, tworzy ściśle ze sobą związaną jednorodną całość kompozycyjną. Budynki są ściśle ze sobą związane na przykład pod względem wielkości i stylu, tworząc jedną całość przestrzenną z ustaloną hierarchią poszczególnych elementów. Zmiana którejś z części tej całości, wstawienie nowej, o innej wielkości i w innym 
stylu, może spowodować zmianę w całości kompozycji i wywołać wrażenie ubytku czy błędu. W wyniku rozwoju urbanistycznego, współczesne panoramy niektórych miast o genezie średniowiecznej, utraciły swoją dobitność, spoistość i jednoznaczność. W widokach pojawiły się kolejne dominujące elementy, akcenty, zwykle zaburzające zastaną, istniejącą hierarchię form w kompozycji. Panoramy niektórych współczesnych miast stały się kompozycjami bardziej swobodnymi.

Według Żórawskiego zależności pomiędzy częściami formy są mniejsze, jeśli forma jest mniej spoista, czyli bardziej swobodna [Żórawski, 1973, s. 32]. Jeśli kompozycja miasta jest mniej zwarta, a budynki są rozmieszczone bardziej swobodnie, to może oznaczać, że jej poszczególne części nie są ze sobą związane żadną zasadą kompozycyjną. Ta swoboda i brak konkretnej idei kompozycyjnej będą widoczne również w panoramie takiego miasta.
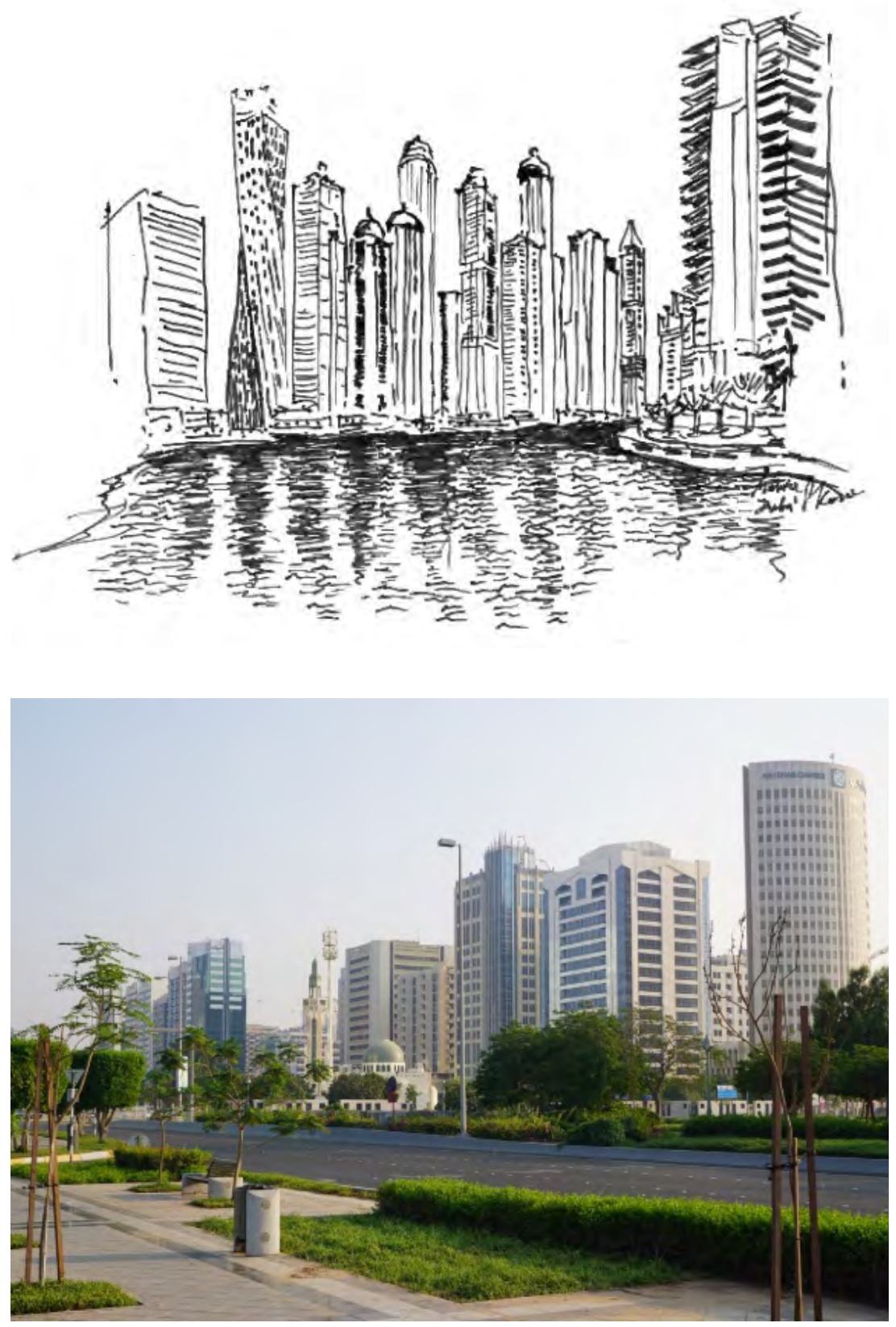

Ryc. 1. Dubaj Marina, rytm dominant. Wszystkie budynki są podobnej wysokości więc uwagę przyciąga charakterystyczny kształt skręconego budynku [rys. K. Sobczyńska i in., 2020, s. 130]

Ryc. 2. Abu Dhabi, panorama miasta składa się z wielu usytuowanych obok siebie, wieżowców, z których każdy mógłby pełnić rolę dominanty, gdyby stał wśród niższych budynków. W tym przypadku trudno znaleźć punkt główny kompozycji [fot. K. Sobczyńska] 
Analizując stwierdzenie Żórawskiego "forma jest czymś więcej niż sumą części” [Żórawski, 1973, s. 35] należy zauważyć, że forma, która składa się z mniejszych części, sama często też jest częścią większej całości przestrzennej. Żórawski zauważa też, że kiedy dana forma staje się częścią większego układu kompozycyjnego, to zwykle traci ona swą indywidualność na korzyść całego układu, którego stała się częścią. Forma ta zaczyna wtedy pełnić inną rolę niż wcześniej, gdy była pojedynczą formą. Te stwierdzenia odnoszą się również do panoram miejskich. W panoramie miasta poszczególne budynki układają się w sylwetę miasta, tworzą kształt i formę, jednak ta sylweta jest też częścią większej przestrzeni, na przykład naturalnego krajobrazu nadbrzeża nad rzeką.

Na przykład panoramy bogatych ekonomicznie, współczesnych miast, takich jak Dubaj czy Abu Dhabi, składają się z wielu usytuowanych obok siebie, wieżowców. W europejskich miastach, które narastały na przestrzeni wieków, każdy z tych wieżowców mógłby pełnić rolę dominanty, gdyby stał wśród niższych budynków. Tutaj jednak, taki budynek-dominanta, stojąc wśród innych, równie wysokich, interesujących i okazałych, traci swoją dominację na rzecz całej kompozycji [Sobczyńska, 2020, s. 123-126]. Tendencją człowieka obserwującego jakąś formę czy kompozycję z pewnej odległości jest poszukiwanie punktu głównego, dominanty układu. Patrząc na panoramy tego typu miast jak Dubaj czy Abu Dhabi, znalezienie jednego punktu głównego jest raczej niemożliwe, ponieważ tych punktów jest wiele. I tu, w tym przypadku, podczas oglądania tego typu miasta, uruchamia się intensywniej, tendencja człowieka do grupowania elementów w grupy, następuje poszukiwanie rytmów i różnego rodzaju innych zależności, łączących budynki widziane w panoramie miasta.

W miejscu, gdzie istnieje wiele dominant obok siebie, trzeba uchwycić ich rytm i znaleźć inne zależności kompozycyjne, a także uchwycić wrażenie pochodzące od całości. Zapamiętanie grupy okazałych wysokich budynków, brył geometrycznych jest trudniejsze niż zapamiętanie panoramy małego miasta, ze względu na dużą ilość dominant i brak widocznej, jednoznacznej hierarchii. Wśród wielu podobnych obiektów, uwagę obserwatora przyciągnie budynek o charakterystycznym kształcie i on będzie pełnił rolę tego "najważniejszego" w kompozycji. Ten budynek w pewien sposób narzuci hierarchię. W widoku Dubaj Mariny uwagę obserwatora przyciąga charakterystyczny skręcony budynek, wyróżniający się kształtem i dynamiką. Charakterystyczne są również zwieńczenia niektórych budynków, w postaci kopułek.

Według Żórawskiego formowanie kompozycji nie odbywa się poprzez dodawanie części lecz poprzez łączenie i zestawianie części zgodnie kierunkiem i dyscypliną stanowiącą główną wartość "formy-matki”. Forma choć jest złożona z części, stanowi nową indywidualną całość [1973, s. 35]. Według autorki projektowanie kompozycji przestrzennej w każdej skali, od urbanistycznej po architektoniczną, nie powinno odbywać się poprzez dodawanie i sumowanie poszczególnych elementów, ale powinno być czymś w rodzaju łączenia i zestawiania zgodnie z jakimś głównym kierunkiem i ideą kompozycyjną większej całości. To odnosi się również do miasta widzianego z pewnej odległości: choć jest ono kompozycją złożoną z części, to stanowi jednak nową indywidualną całość czyli formę, zdefiniowany kształt. Skoro, jak twierdzi Żórawski, forma jest całością ze ściśle związanymi ze sobą różnymi zależnościami, częściami, dodanie do niej nowego elementu, nie powinno następować dowolnie, ponieważ działanie to może spowodować duże zmiany w zastanej kompozycji.

Autorka pragnie zwrócić uwagę, że nieprzemyślane wprowadzanie do przestrzeni miasta nowych elementów może spowodować zmianę kompozycji całości, a także zmianę ról, jakie pełnią poszczególne części kompozycji miejskiej panoramy. Na przykład, gdy wewnątrz miasta, w jego centrum, powiedzmy na głównym placu, pojawi się kolejna dominanta, to zmieni ona role istniejących już tam akcentów oraz hierarchię wszystkich elementów kompozycji. Będzie to zauważalne również w panoramie miasta, w której zmieni się rytm dominant, co w rezultacie może zmienić też kształt sylwety miasta.

\section{Panorama miasta jako zbiór form na tle}

Oglądając jakąkolwiek kompozycję człowiek zazwyczaj skupia uwagę na jednym punkcie jako formie na tle. Panorama miasta, jak każda kompozycja jest więc zbiorem form na tle. Tłem dla panoramy miasta są najczęściej elementy neutralne, takie jak zieleń, czy akweny wodne. W widoku panoramicznym miasta dla dominant architektonicznych oprócz zieleni, tłem może być również jednorodna zabudowa, pozbawiona wyróżniających się akcentów. Formami na tle zwykle są elementy wyróżniające się od pozostałych, na przykład kształtem, wielkością bądź barwą. Generalnie obecność akcentu na tle, wyróżniającego się spośród innych elementów, nadaje kompozycji hierarchii i wywołuje poczucie uporządkowania, a to sprawia, że dana kompozycja jest łatwiejsza do 
zapamiętania [Sobczyńska, 2020, s. 124]. Obecność głównego punktu czy elementu kompozycji, który nadaje charakterystyczny kształt całemu układowi bądź sam posiada charakterystyczną formę, jest cechą indywidualizacji przestrzeni, ułatwiającą rozpoznawalność i identyfikację miejsca.

\section{Hierarchia kompozycji. Punkt główny w panoramie miasta}

Każda panorama jest swoistą kompozycją składającą się z wielu elementów. Jak w każdej kompozycji ważna jest tu hierarchia poszczególnych elementów, to znaczy, że znajdują się tu elementy ważne, przyciągające uwagę obserwatora oraz elementy mniej ważne, jako tło dla tych pierwszych lub jako "reszta”, wypełniająca całość panoramy. Większa ilość elementów akcentujących w panoramie tworzy na ogół pewien rytm, od którego zależy, czy dana kompozycja jest mniej lub bardziej czytelna i zapamiętywalna. Charakterystyczną formę posiadają panoramy średniowiecznych miast europejskich. Nieodłącznym elementem ich kształtu są dwie lub jedna dominanta w postaci wieży, górującej nad niższą zabudową.
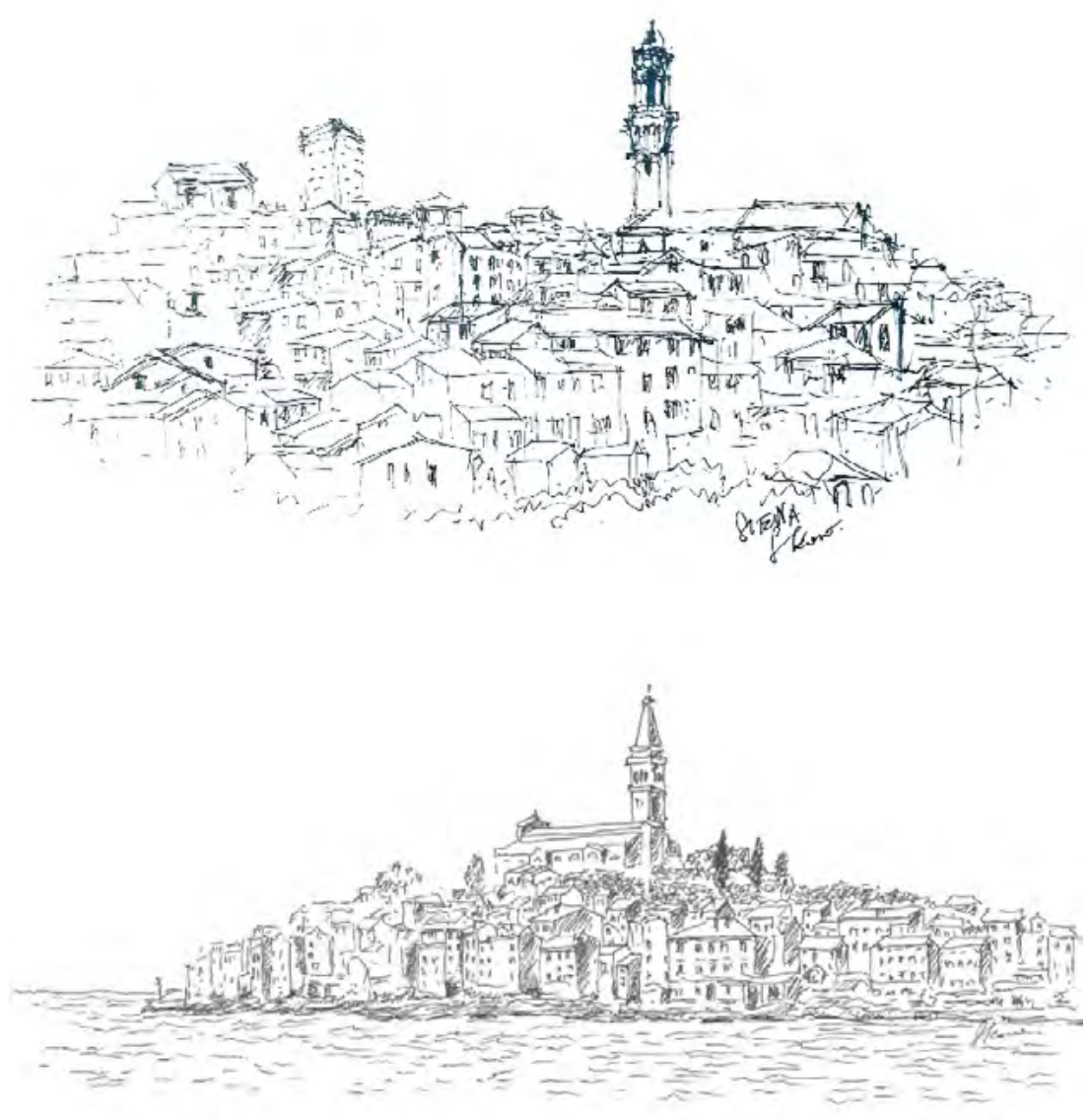

Ryc. 3. Siena, charakterystyczna sylweta średniowiecznego miasta z dominantą [rys. K. Sobczyńska 2020]
Ryc. 4. Rys. 4. Rovinj. Dominanta, wieża kościoła wskazuje lokalizację centrum miasta. Woda i niebo stanowią jednorodne tło dla sylwety miasta, umożliwiając zobaczenie jej jednoznacznego konturu [rys. K. Sobczyńska]

Średniowieczne miasta narastały w sposób naturalny wraz z naturalną hierarchią, począwszy od budynków najważniejszych, należących do możnowładców i władzy miasta (zamek, ratusz) oraz budynków kultu religijnego, poprzez domy rzemieślników, a skończywszy na zagrodach wiejskich na obrzeżach miasta lub poza jego murami. W widoku miasta z pewnej odległości, wieże ratusza i kolegiaty wskazują, gdzie znajduje się centrum miasta, jego najważniejsza część [Sobczyńska, 2020, s. 124]. 
Na wrażenie przestrzenności, atrakcyjności formy miasta w widoku panoramy miejskiej mają wpływ: odbicie w wodzie oraz obecność zieleni, której kontrastowa w stosunku do architektury, miękka faktura stanowi doskonałe wypełnienie formy, sylwety miasta lub tło dla obiektów architektury.

\section{Wnioski}

Celem artykułu było zwrócenie uwagi na istotny aspekt projektowania urbanistycznego jakim jest kształtowanie kompozycji. Wykorzystując rozważania Juliusza Żórawskiego nad budową formy architektonicznej autorka przeniosła jego podstawowe postulaty na pole projektowania urbanistycznego, a konkretnie kształtowania miejskich panoram. Współcześnie w projektowaniu urbanistycznym rzadko uwzględnia się kształtowanie widoków panoramicznych miasta, a przede wszystkim powstające w nich przestrzenne konsekwencje podejmowanych decyzji projektowych. Panoramy miast jawią się człowiekowi jako formy i kompozycje widziane. W widokach panoramicznych ważne są więc cechy i elementy, oddziałujące głównie na zmysł wzroku, czyli forma, kształt, kontur, kompozycja form i ich wzajemne zależności, rozmieszczenie dominant, barwa, światłocień, zieleń, odbicie w wodzie, itp. Niestety panoramy wielu współczesnych miast, na skutek pojawienia się nowych akcentów, utraciły hierarchię swojej kompozycji, a przez to czytelność i jednoznaczność. Według autorki, zasady percepcji i postrzegania formy powinny być jedną z wytycznych kształtowania przestrzeni miasta, w tym widoków panoramicznych [Bardzińska-Bonenberg, Sobczyńska, 2018].

Autorka pragnie zwrócić uwagę, że projektowanie urbanistyczne nie powinno ograniczać się do projektowania w dwóch wymiarach i uwzględniania obowiązujących normatywów. Projektując współczesne inwestycje w mieście, architekci-urbaniści powinni brać pod uwagę również widoki zewnętrzne miasta i zmiany w nich zachodzące, na skutek projektowanej zabudowy. Szczególnie rozważnie powinno się ingerować w kompozycje panoram miast średniowiecznych, gdzie panuje silna hierarchia akcentów i dominant. Potrzeba dużo wrażliwego wyczucia kompozycji panoramy jako formy i równie wnikliwych analiz tej formy jako kompozycji. Należy więc dołożyć starań, by nie zmieniać istniejących pierwotnych założeń kompozycyjnych czy hierarchii elementów, bo tego typu zmiany zwykle doprowadzają do utraty wyrazu i wcześniej założonej idei kompozycyjnej, a przez to utraty czytelności i jednoznaczności. Autorka zdaje sobie sprawę, z konieczności powstawania w miastach budynków wysokich, jednak dbałość o istniejącą kompozycję panoramy miasta, poprzez stosowanie na przykład zieleni, umożliwiającej płynne przejścia pomiędzy różnymi wysokościami, może redukować skutki drastycznych rozwiązań przestrzennych. Warto pamiętać, że kształt sylwety panoramy danego miasta jest często charakterystycznym elementem jego indywidualności, którą należy zachować i pielęgnować.

\section{Literatura}

[1] Bańka A., Społeczna psychologia środowiskowa, WN Scholar, Warszawa 2002.

[2] Bardzińska-Bonenberg T., Sobczyńska K., Greenery, a historical townscape marker and stimulator. Poznan as a case study, "Space \& Form", no. 33, 2018, s. 9-42.

[3] Barek R., Graczyk R., Jastrząb T., Marmur M., Matusewicz T., Siewczyński B., Słuchocka K., Szeszuła W., Ast R., Sobczyńska K. red. Ast R., The colour and shape of the city panorama in different cultures. Perception and painting experience, [w:] Arte 2: artistic works of workers and supporters of Department of Urban Design Faculty of Architecture of Poznan University of Technology / Poznan University of Technology, 2020, s. 123-140.

[4] Sobczyńska K., Zieleń jako element współczesnego miasta i jej rola w przestrzeniach publicznych Poznania, Rozprawa Doktorska, 2014, obrona 23.09.2014 r.

[5] Wejchert K., Elementy kompozycji urbanistycznej, Warszawa 1984.

[6] Żórawski J., O budowie formy architektonicznej, Wydawnictwo Arkady, Warszawa 1973. 


\title{
Perception of form as guidelines for creating a city panorama
}

\begin{abstract}
The panorama of the city, like any other space, is a composition composed of many forms. The perception of the city's panorama will therefore be the perception of the form, shapes, rhythms of elements and their hierarchy. Architectural space evokes many sensations in the observer. It is understandable for man and perceived as legible if it is clearly and unambiguously formed. Therefore, the principles of perception should be one of the guidelines for creating the city space, as well as its panoramic views. The shape of the city silhouette in panoramic views is often an element of its individuality, hence the importance of maintaining the principles of the existing composition and hierarchy.
\end{abstract}

Keywords: panorama, perception, form, composition, hierarchy 